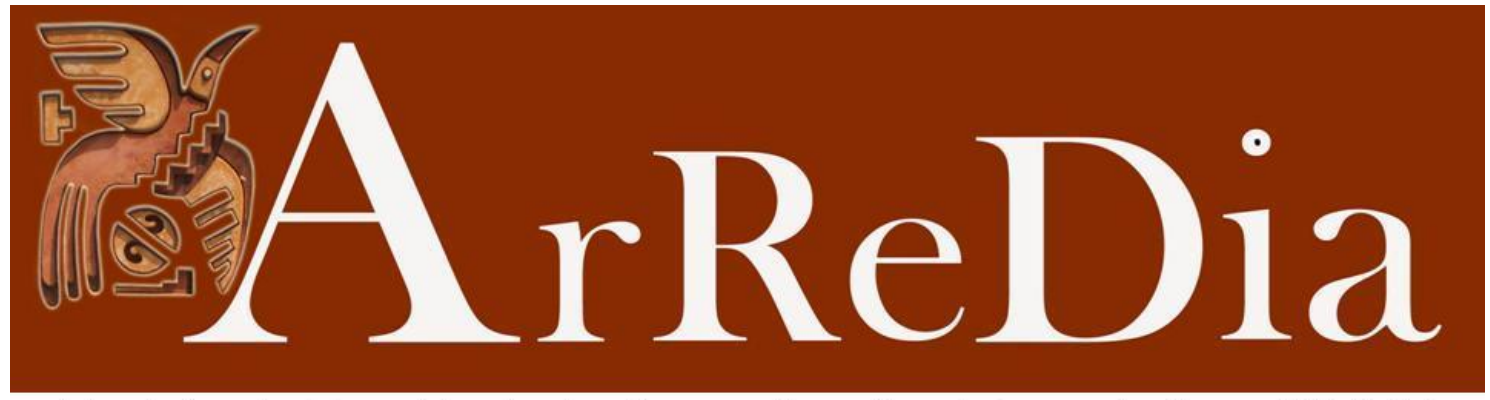

Revista da Faculdade de Comunicação, Artes e Letras / UFGD

João Alexandre Alves dos Santos ${ }^{i}$ Universidade Federal da Grande Dourados

\title{
Estória da Bela Dona, setiético louco amor
}

Neste verso pouco alçado,

Tranquilo invoco a rainha realço o voo alçado; do mistério da rainha o mistério do condado.

Avistado o matuto sitiante no próprio debuxo ínfimo e hilário mergulhado em seu jeito artilante da arte de ignorar os ignórios. de esboçar-se em ser pensante;

Conte-me a história, seu senhor, Quem sabe, sabe. Quem não sabe do mistério dos mistérios do condor, vai buscando cansado o segredo, se assim se cabe.

do plano fundo, a rainha do amor.

Dois entrelinhados sonhos amigados.

e assanhando-se ao moço vagante, Fartou-se, pois, da moça os olhos novados,

fitou-os, outrora, a mal costume d'antes. intercalando-se dois que se eram amados;

Viu em - devaneio e - poço fundo a resposta errante:

"Seis e quanto mais sois? Não, não será.

A querida virtude confiante não terá.

Sei que pouco sei matutando aqui a sós, mas sei mais que de meu bem sei, muito mais, que matar-te-ei!"

Decidida como só ela, os sábios lábios d'outra fera calou a voz mais bela; enganaram a dama, como assim quisera. 
Vedes como lindos eram os lábios dela... dizia.

E o vagante, atirou-o em pouco largo, mas fundo;

por azar errante,

sem nem pensar afundo.

ao poço geante

Essa é a estória da rainha errante,

Seu amor, em prantos n'outro mundo,

que no poço fundo o achou hostilizante.

descobriu: até mesmo o misterioso ramo profundo, se perdido ou improfundo,

transforma a bela mais meiga dona senhoria

em assassina inconstante.

i E-mail do autor: xandy_brother@hotmail.com 